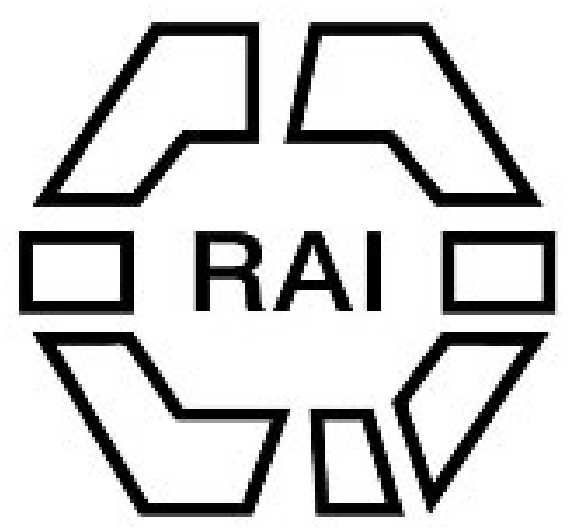

Some Animistic Beliefs Among the Yaos of British Central Africa Author(s): Alexander Hetherwick

Source: The Tournal of the Anthropological Institute of Great Britain and Ireland, Vol. 32 (Jan. - Jun., 1902), pp. 89-95

Published by: Royal Anthropological Institute of Great Britain and Ireland

Stable URL: http://www.jstor.org/stable/2842905

Accessed: 15/06/2014 08:55

Your use of the JSTOR archive indicates your acceptance of the Terms \& Conditions of Use, available at http://www.jstor.org/page/info/about/policies/terms.jsp

JSTOR is a not-for-profit service that helps scholars, researchers, and students discover, use, and build upon a wide range of content in a trusted digital archive. We use information technology and tools to increase productivity and facilitate new forms of scholarship. For more information about JSTOR, please contact support@jstor.org. 


\title{
SOME ANIMISTIC BELIEFS AMONG THE YAOS OF BRITISH CENTRAL AFRICA.
}

\author{
By the Rev. Alexander Hetherwick, M.A., F.R.G.S., of the Blantyre \\ Mission, British Central Africa.
}

THE original home of the Yao tribe may be roughly described as the large and lofty plateau which lies to the east of Lake Nyasa, and is bounded by the Rivers Rovuma and Lujenda. Forty years ago, about the time that Livingstone first entered the country, they began to be pressed on the north by the Magwangwara, and on the east by the Makuwa tribes. These invasions caused them to move, some westward down to the shores of Laka Nyasa or the banks of the Upper Shire River, and others southward to the Shire Highlands, Mount Zomba and the eastern slopes of Mount Mlanje. In every case they susceeded in either subjugating or expelling the original Maravi or Mang'anja inhabitants of these districts, and in no case have they lost their own independence.

Till about fifty or sixty years ago the Yaos were untouched by any external influences, and when at that time the Arab and coast trader from Kilwa and Zanzibar began to treat and trade with them they appear to have been little affected by contact with these visitors. Only a few of the younger men aped at following Mahommedan tenets, and these they only grafted on to their still cherished belief in the old faiths of their fathers. The Koran, or a few of its texts, was added to the many other charms they had already hung about their necks. The faith which the first missionaries found them in possession of when they entered the country twenty-five years ago may therefore be held to be the unadulterated creed of the tribe from time immemorial.

The foundation of the Yao religion is to be found in the lisoka, the soul, shade or spirit which every human being possesses, and which is the inspiring agent in his life. They profess to give no definite description of the nature or characteristics of this soul. In their minds however it is allied with the shadow, and would seem to bear to the body the relation which a picture has to the reality. Their word for a shadow is chiwiliti, which is also the term that they use to denote a picture, and pictures they associate with the shades or shadows of the dead. I have known natives refuse to enter a room where pictures were hung on the walls " because of the masoka, souls, which were in them." The photographic camera was at first an object of dread, and when it was turned upon a group of natives they scattered in all directions with shrieks of terror. "The European," 
they said, "was about to take away their shadows and they would die." In their mind the lisok $\alpha$ was allied to the chiwilili or picture, and the removal of it to the photographic plate would mean the disease or death of the shadeless body.

As an instance of their faith in the close relationship of the lisoka and the picture or shadow, I may relate the following incident. An influential Yao chief on Mount Zomba with whom I was on terms of intimate friendship for years, refused to allow himself to be photographed, fearing the consequences on his life. At last I was able to persuade him to give me a sitting, but on the sole condition that the picture was to be shown to none of his subjects but to be sent out of the country as soon as possible. He feared lest some ill-wisher might use it as a means towards his bewitchment. Some months afterwards' the chief became seriously ill, and in the minds of his attendants his illness was attributed to some accident having befallen the photographic plate on which they believed the picture of their chief to be imprinted. If that negative had been broken in England, whither it had been sent, their chief's illness would be accounted for. Accordingly they appealed to the divining oracle, who, however, after consulting the "lots," assured them that the picture was intact, and that in consequence the disease must be ascribed to some other cause.

The lisoka or soul is recognized as the chief agency in dreams. To dream is, in the Yao tongue, kusagamila masoka, where masoka is the plural form of lisoka. The lisokc is supposed to go out and visit the scenes and persons it dreams about, and in turn is visited by the masoka of others, dead or living. Pains in the body on rising from sleep in the morning are usually attributed to such nocturnal visits, while disease or pains of a severe type are ascribed to castigations by the whips of the masoka or more frequently of the witches who prowl around during the night watches.

Madness, idiocy and the ravings of delirium or disease are accounted for by a similar agency. The sufferers are wa masoka, they of the spirits, and a sudden fit of epilepsy or insanity is described as gakamwile masoka, the spirits have seized him. Such persons are usually regarded with awe, as living in close contact with the unseen, but no incantations or enchantments are ever used to expel the spirit in possession. Some native doctors are credited with a knowledge of certain medicines which they say are effectual in such cases, but their application in no way differs from those employed in treating ordinary types of disease. Idiots and the insane are allowed to wander at will about the village, and only when violent symptoms show themselves as a danger to the community is any physical restraint put upon them.

The masoka are also recognized as the inspiring agencies in the ravings of the witch detective. This person, usually a woman, is called in to discover who is the guilty agent in cases of mysterious deaths or outbreak of an epidemic at a village. She arrives on the scene and takes up her abode for a few days previous to her actual demonstration. She mixes with the people, learns all the scandal and gossip of the community, and at night prowls about the houses searching for 
evidence. On the appointed day she dances, kuyina masoka, to dance the spirits, or kuweweta, to rave or prophecy, and in the ravings of the dance she calls out the name of some party who is afterwards accused of leing the msawi or witch. Followed by a crowd of excited spectators she dances through the village spear in hand, stopping here and there to dig up charms or medicines which the supposed witch has buried in the ground as the instruments of his occult practices. It is only in cases of supposed special difficulty, or when the magnitude of the supposed crimes demands that special measures be adopted for their detection, that the services of such a witch detective are called in. In ordinary cases these appeals are made to the divining oracle who consults his "lots" as a means of discovering crimes of this nature.

Among the Yaos the human being is believed to be the sole possessor of a lisoka. I have been unable to discover any trace of a theory that the lisoka may pass into any animal or inanimate object and thus confer upon it the nature or power of a fetish. Such belief is cherished arnong the Angoni and Achewa tribes to the westward by Nyasa and the upper Shire River, and the intelligent Yao is aware of this, but he states that among his people no such belief exists. Even charms which have the effect of healing or warding off disease, or of protecting the wearer from war or wild beasts or other danger by land or water, are supposed to possess this power without any idea of their being possessed by a lisoka or other spirit influence. The nearest approach to such a theory is in the case of certain powerful "doctors" who have obtained special medicine by means of which, at death, they can transform themselves into lions, leopards, crocodiles, etc. Lepers also are sometimes supposed to become hippopotami. But both of these cases must be regarded rather as transmutations of body than transmigrations of soul.

It will be thus seen that the nature of the human lisoka is closely allied to that of the masoka, which are the inspiring agents in madness and in the ecstasy of prophecy or incantation. What the origin of these inspiring masoka is, or to whom they belonged when in bodily life, the Yao holds no theory. He is content to accept them as they are, masoka iyoyo, "Just nasoka and nothing more," as he says.

It is, however, when we follow the disembodied lisoka after death and consider its position and power in the other world that we find ourselves in a region of higher spiritual activities.

In dreams or in fainting fits the lisoka leaves the body but only to return to it with the awakening consciousness. At death, however, it leaves its earthly abode never to return. It is now spoken of as having gone to mulungu or mlungu. This word, which lies at the basis of all Yao theories of the place of the soul after death, will be dealt with later on as regards its derivation and connections in the Bantu family of languages. In its actual use it bears two significations.

I. The word mulungu is in the first instance applied to the human soul or lisoka after death when it is considered as an inhabitant of the spirit world. Even in life a man, when he meets with any piece of good luck, will be heard to say, "It's my mulungu," as if his soul had an influence in determining the character of his 
present fortunes. But it is to the human soul after death, when it is considered as having an influence on the lives and fortunes of those it has left behind in the world and consequently as a power to be propitiated and honoured, that the term mulungu is more strictly applied. Freed from the body it passes to mulungu, and there is regarded as endowed with powers which it never possessed when alive on earth. To pray to such a spirit is described as kulomba mulungu, to worship mulungu, never lisoka in this case. Such mulungu worship enters largely into Yao religious or social life. In almost every Yao village there will be found a shrine which is the centre of the worship of the inhabitants. It consists of a carefully built hut enclosed within a strong grass fence or hedge of a species of cactus plant. The hut itself is built of the usual native materials-the walls of wooden posts, bamboos, and strong reed grass bound together with bark-rope and plastered over with clay or stiff mud. The roof is of grass laid on a framework of bamboos, and is generally covered with long strips of white or coloured calico. On the ridge or apex of the roof are fixed a couple of flags or an umbrella or two. One wall is usually left open so that the interior is easily seen. Within, from the bamboo rafters are suspended handkerchiefs, cloths, bunches of beads, etc., all offerings to the mulungu of the dead headman or chief from his friends and relatives. The floor is of clay carefully smeared with sand in native fashion. A raised platform or mound of earth in the centre marks the spot where the grave was made. The awilo or officials who preside at the funeral obsequies, first dug for about 8 or 10 feet down in a perpendicular direction, and then on the western side of this well they hollowed out a shallow cave in the earth. In this the body was placed, laid on its side with the knees bent up under the chin, and the face turned towards the east. Various articles of personal property were next placed beside the corpse, clothes, ivory, guns, axes, hoes, etc., and the mouth of the cave closed up with wooden posts and a strong reed mat. The grave was then filled in and the surface carefully finished as we have seen. At the head of the mound a native pot was fixed in the ground for the reception of the offering of beer which is an almost invariable accompaniment of any act of worship paid to the mulungu of the dead.

Such a shrine marks the grave of almost every Yao chief or headman, and is regarded as the abode of his soul or the spot where his mulungu is most accessible. If his successor is about to undertake a long journey or enter on any warlike expedition against an enemy or neighbour, he must first leutaga mbepesi, place an offering here to secure the favour and assistance of the mulungu of the dead. Should a long-continued drought endanger the prospects of the grain crop, the departed chief must be solicited to send the lacking rain. A feast is first prepared, almost always of beer, sometimes with the addition of native porridge, fowl, or game. The worshippers gather round the shrine bringing part of the food which they have prepared. Their priest for the occasion is the successor of the dead chief, sometimes one or other of the awilo who placed the body in the grave, or it may be that any other near relation of the dead man is chosen to represent the people and act as their spokesman. The nearer the relationship the more influence will he have 
with the dead. He approaches the shrine, opens the gate of the fence, takes a potful of beer and pours it into the pot at the head of the grave. Next he places the basket of porridge and the plate of meat on the mound beside it and retires. Kneeling down outside the gate facing the shrine and a few yards in front of the people he chánts his prayer in a monotone, each petition commencing with "Chonde, chonde," "Please, please." All the while the people clap their hands in unison with him and sing the response as they do in a native case in the chief's court.

When the offering has been made at the grave, the rest of the beer or other food is consumed by the worshippers. Guns are fired as a token of respect to the dead, and the rest of the day is spent in dancing.

Such shrines are to be seen in almost every Yao village where the inhabitants have been located for any length of time. They are regarded with awe-the little boys as they pass whisper to each other in a warning tone, "masoka." Should the village be moved to any other district, the old shrine is not forgotten. Periodical visits are made to it with the usual offerings. In cases where the old home has been occupied by a people hostile to the old inhabitants, such visits are usually made during the night, and the people awake in the morning to find that the old chief's grave in their midst has been newly repaired, and a fresh offering of food placed at its head.

Sometimes such shrines are found on the summits of hills which once may have been a refuge from the enemy in time of war, but which now lie lone and deserted. Thither in their need the people make their way with their offering of food and beer, and their prayer for raị or suitable weather for the crops. Near Blantyre such shrines are to be seen on the tops of Mount Sochi and Mount Michiru. The former is the abode of the spirit of Kankhomba, and the latter of Mpalale, both old Maravi or Mang'anja chiefs who doubtless fled there seeking safety from the war of the invading Yaos, and died leaving their masoka to be the mulungu or spirit of the mountain. Some years ago, during the fear of an Angon, invasion, the Yaos of Mount Sochi fled to the hill-top for refuge, and there the old chief Kapeni died. He was buried close to the grave of the old Kankhomba, and now, when the Yaos on Sochi make an offering, it is to the spirit of Kapeno that the homage is paid, and the shrine of Kankhomba lies neglected.

Only the graves of chiefs or headmen are thus treated as shrines of worship The burying place of slaves and the common people lies away in the thick bush, where only the rank grass or the thicket of old trees marks the spot. No offerings are ever taken there, for such as are buried there can have no influence in the spirit world. The dead are buried, the broken pot or basket is left on the grave to mark the spot, and none ever seek to go there save to lay another in the same neglected ground.

II. But the word mulungu is used by the Yao with a wider application. Etymologically the. word is connected with the root kulungwa, which in so many of the other branches of the Bantu tongue appears as kulu or kuru, and signifies "great" or "old." It is the same root which appears in the Kaffir word for God, 
Unkulunkulu, which may therefore be rendered as "The old, old One," or "The great, great One." A like rendering may be given of the Yao form mulungu, the " Old One," or the "Great One." In this or a modified form muzunu (Swahili) it appears in all the Eastern group of the Bantu tongues as the equivalent for "God" (see Father Torrend's Comparative Grammar of South African Bantu Languages). To trace it as Father Torrend does to any connection with Moloch, the god of the Phœnicians, is to attach undue weight to a chance coincidence of sounds.

As we have already seen, the word mulungu is applied to the human lisoka when regarded as an object of worship, or as an inhabitant of the spirit world. But it is also used to denote that spirit world in general, or more properly speaking, the aggregate of the spirits of all the dead. The plural form of the word is rarely heard, unless when the allusion is made to the souls in their individualities. In its native use and form the word does not imply personality, for it does not belong to the personal class of nouns. Etymologically it is classed with the leg, heart, arm, head, etc., of the human frame. Its form denotes rather a state or property inhering in something, as the life or health inheres in the body. Among the various tribes where the word is in use as we have described, the missionaries have adopted it as the term for "God." But the untaught Yao refuses to assign to it any idea of being or personality. It is to him more a quality or faculty of the human nature whose signification he has extended so as to embrace the whole spirit world. Once after I had endeavoured to impress an old Yao headman with the personality of the Godhead in the Christian sense of the term, using the term Mulungu, my listener began to talk of "Che Mulungu," "Mr. God," showing that originally to him the word conveyed no idea of the personality I was ascribing to it.

And yet the Yao approaches closely to the idea of personality and a personal being, when he speaks of what mulungu has done and is doing. It is mulungu who made the world; and man, and animals. Far in the interior of the continent, toward the north-west, beyond the plains and swamps of the Loangwa River and Lake Bangweolo, there lies, in Yao legend, an island in the midst of a lake called Kapiritimya. On that island there is to be seen a large flat rock marked by the footprints of men and animals of all kinds. When that rock was once a heap of moist clay, mulungu created all living things and sent them across the soft mass, where their footprints remained to be afterwards hardened into the imperishable rock. Such is the Yao legend of the creation of the world, and mulungu is always the Great Creator.

Mulungu is also regarded as the agent in anything mysterious. "It's mulungu," is the Yao exclamation on being shown anything that is beyond the range of his understanding. The rainbow is always "mulungu," although some Yaos have begun to use the Mang'anja term " uta wa Lesa," bow of Lesa.

Offerings are made to the spirit world or to mulungu as the great agency in the affairs of human life. Outside the village, or beside the headman's hut, may often be seen a rough shed. In this are placed the first-fruits of the new crop, 
green maize, beans, pumpkins, peas, etc., as a thankoffering from the villagers for their harvest. This is described as kulomba mulungu, to worship mulungu. At the foot of the tree in the village courtyard, where the men sit and talk or work, an occasional small offering of flour or beer is placed on any special occasion in the life of the village or any of its inhabitants. This also is kulomba mulungu. A devout native sitting down to a meal will, before beginning to eat, take out a small morsel of the food before him and throw it at the root of the nearest tree as an offering to mulungu. On a journey a traveller will sometimes stop and lay a little flour in a pyramidal heap at the foot of a tree by the wayside or at an angle where two roads meet. This, like the others, is for mulungu, the spirit world, the guardian of the wayfarer on his journey.

Thus the Yao presents us with three stages of animistic belief :-

(1) The human lisok $a$ or shade, the agent in dreams, delirium, etc.

(2) This lisole regarded as mulungu, and an object of worship and reverence, the controller of the affairs of this life, the active agent in the fortunes of the human race.

(3) And lastly, mulungu as expressing the great spirit agency, the creator of the world and all life, the source of all things animate and inanimate.

And yet between these three conceptions of the spirit nature no definite boundary line can be drawn. The distinction in the native mind is ever of the haziest. No one will give you a dogmatic statement of his belief on such points.

It is only through long association with them in their daily life noting actual expressions of opinion or hearing of definite acts in relation to their worship or their dead, that one can get behind the reserve with which every Yao man or woman approaches or alludes to the spirit world which lies beyond and after this. 